\section{Calla Lily Growth and Development Under Saline Irrigation}

\author{
Maren E. Veatch-Blohm ${ }^{\mathbf{1}}$ and Lindsay Morningstar \\ Biology Department, Loyola University Maryland, 4501 N. Charles Street, \\ Baltimore, MD 21210
}

Additional index words. Zantedeschia, 'Flame', 'White Alba', 'Pink rehmannii', ion distribution, salt stress

\begin{abstract}
Salinity is a problem for crop production worldwide, which can affect not only the yield of ornamental plants, but also their quality. Calla lilies (Zantedeschia K. Koch) are a popular cut flower and landscape plant. In this study we examined how salinity applied either pre- or post-emergence altered shoot growth and flower production compared with standard growth conditions. Salinity applied post-emergence did not significantly affect shoot growth in either the 25- or 50-mM NaCl treatments; however, irrigation with a 50-m $\mathrm{NaCl}$ solution did significantly reduce dry weight and flower production compared with the control. The most drastic effect on flower production was observed when the 50-mm treatment was applied pre-emergence. Although flowering time did not vary among treatments, in the spring, flowering success was less than $50 \%$ in the 50-mu treatment, which was significantly less than the other treatments. The plants in all treatments had good visual quality and high relative water content although the shoots of the salt-stressed plants had a $\mathrm{Na}^{+}$content two to five times greater than the control. We hypothesize that the maintenance of visual quality may in part be the result of increased $\mathrm{Ca}^{2+}$ concentration (up to four times the amount in the control) in the shoots of the saltstressed plants, which may have helped maintain turgor and cell membrane integrity under saline conditions. Our results indicate that use of irrigation water salinized by $\mathrm{NaCl}$ with an electrical conductivity (EC) more than twice as high as that recommended for optimal calla growth $\left(1.5 \mathrm{dS} \cdot \mathrm{m}^{-1}\right.$ compared with $\left.3.4 \mathrm{dS} \cdot \mathrm{m}^{-1}\right)$ can be used without a loss in plant quality, thereby increasing irrigation options for calla lilies, particularly in areas where high-quality water is scarce.
\end{abstract}

Currently, salinity affects up to one-third of all irrigated agricultural land worldwide and the areas affected are increasing (Carter et al., 2005; Cassaniti et al., 2009; Munns and Tester, 2008; Shibli et al., 2007). Salinity is particularly a problem in arid and semiarid areas where high-quality water is being used directly for human consumption rather than for irrigation, increasing the probability that irrigation will be with water that has an EC that is not optimal for plant growth (Arabiyat, 2005; Carter et al., 2005; Cassaniti et al., 2009; Grattan, 2002; Grieve et al., 2008; Marcum, 2006; Shillo et al., 2002). Salinity exposure in plants can result in stunting (Francois and Clark, 1978; Shannon and Grieve, 1999), chlorosis, and necrosis (Wong, 2005); reductions in chlorophyll content (Charbaji and Ayyoubi, 2004); and reductions in photosynthetic rate (Wang et al., 2001). Reductions in growth and visual plant quality may be related to physiological drought imposed by saline conditions (Gupta et al., 1995), direct ion toxicity (Gupta et al., 1995; Shannon and Grieve, 1999), and/or salinity-induced nutrient deficiency, particularly of $\mathrm{Ca}^{2+}$ and $\mathrm{K}^{+}$ (Charbaji and Ayyoubi, 2004; Halperin et al., 1997; Hasegawa et al., 2000; Shibli et al., 2007). Most research on the response of

Received for publication 6 Oct. 2010. Accepted for publication 30 Nov. 2010.

${ }^{1}$ To whom reprint requests should be addressed; e-mailmblohm@loyola.edu. (Wong, 2005), inadequate water applicat or deicing salts (Francois and Clark, 1978; Kaushal et al., 2005).

Ornamental plant materials are in great demand for commercial and landscape applications with production efforts focusing on generating a large number of plants at the lowest possible cost (Kozai et al., 2005; Rout et al., 2006; Xiao and Kozai, 2004). Plants in the genus Zantedeschia K. Koch, referred to as a group as calla lilies, are important ornamental plants in demand internationally throughout the year (Halligan et al., 2004; Leal-Rojas et al., 2007). Both white and colored cultivars are sold (Leal-Rojas et al., 2007) with new colored cultivars being developed to meet the demands of an expanding market (Martens et al., 2003; Schoellhorn, 2004). In addition to their use as cut flowers, the foliage of calla lilies is used in floral arrangements (Skutnik et al., 2001) and the tuberous rhizomes are sold for use as potted and landscape plants (Halligan et al., 2004).

In 2001 calla lilies accounted for $20 \%$ of the cut flower export earnings in New Zealand, second only to orchid export (Aitken et al., 2005; Halligan et al., 2004). Research has been conducted on the feasibility of using $Z$. aethiopica in constructed wetlands to treat wastewater with the dual purpose of water treatment and contributing to the floriculture economy, particularly in tropical and subtropical countries such as Mexico (Belmont and Metcalfe, 2003; Zurita et al., 2008). Within the United States, the prices of cut calla lilies can be as little as $\$ 60$ for a bouquet of 20 to 30 flowers (FlowersandFreshness, 2003; ProFlowers, 1998-2010) or up to $\$ 135$ for 30 large white flowers, which are a popular bridal flower (FlowersandFreshness, 2003; Pacific Callas, n.d.). Even miniature callas can cost $\$ 79$ for a bouquet of 10 (Pacific Callas, n.d.).

Most colored and some white Zantedeschia cultivars are native to cool mountainous regions of South Africa that grow best in welldrained soil and can be damaged by excess moisture (Naor et al., 2005; Schoellhorn, 2004). On the other hand, the white arum lily, Z. aethiopica (L.) Spreng, which accounts for a share of the white calla market, is native to more tropical regions of the Western Cape of South Africa and not only tolerates, but may flourish in very moist wetland conditions (Belmont and Metcalfe, 2003; Schoellhorn, 2004; Zurita et al., 2008). For best quality, the industry standard is to maintain an irrigation water EC of $1.5 \mathrm{dS} \cdot \mathrm{m}^{-1}$ or less while avoiding EC greater than $2.5 \mathrm{dS} \cdot \mathrm{m}^{-1}$ (Camberato et al., 2009; Evans, 2005; Morgan, 2006; Pacific Callas, n.d.). As the price of high-quality irrigation water increases resulting from increased demand, growers may need to look toward other sources of water to lower production costs (Marcum, 2006). This could include using reclaimed and brackish water that can potentially have an EC greater than that recommended for optimal growth (Marcum, 2006). The purpose of this study was to determine how moderate salinities imposed by $\mathrm{NaCl}$ affect calla lily growth, including flower production and developmental timing such as times to emergence and flowering.

\section{Materials and Methods}

Calla lily cultivars. Four calla lily cultivars were used in each experiment. The cultivars 
used for all experiments were consistent except those in Fall 2008, in which one cultivar (Sunshine) was substituted as a result of lack of availability of another ('Pillow Talk'). The three consistent cultivars were Flame ( $Z$. elliotiana ×remannii), Pink Rehmanii ( $Z$. rehmannii Engl.), and White Alba [Z. albomaculata (Hook.) Baille.]. The other two cultivars were Pillow Talk (Z. rehmannii violaceae) and Sunshine (Z. elliotiana $\times$ maculata).

Table 1. Initial and final electrical conductivity of soil effluent $\left(\mathrm{dS} \cdot \mathrm{m}^{-1}\right)$ of calla lilies irrigated with three levels of salinity $(\mathrm{NaCl})$ starting either post- or pre-emergence for 63 and $105 \mathrm{~d}$, respectively.

\begin{tabular}{|c|c|c|c|c|}
\hline \multirow[b]{3}{*}{ Run } & & \multicolumn{3}{|c|}{ Salinity $(\mathrm{mm} \mathrm{NaCl})$} \\
\hline & & 0 & 25 & 50 \\
\hline & & \multicolumn{3}{|c|}{ Post-emergence } \\
\hline & Initial & 0.31 & 3.16 & 5.82 \\
\hline 1 & Final & 0.90 & 6.75 & 12.31 \\
\hline 2 & Final & 1.03 & 6.39 & 10.68 \\
\hline 3 & Final & 0.85 & 7.11 & 10.74 \\
\hline \multicolumn{2}{|l|}{ Season } & \multicolumn{3}{|c|}{ Pre-emergence } \\
\hline & Initial & 0.37 & 3.14 & 6.00 \\
\hline Spring & Final & 1.13 & 10.13 & 17.62 \\
\hline Fall & Final & 0.50 & 7.87 & 12.10 \\
\hline
\end{tabular}

Table 2. Mean \pm SE growth, flower number, shoot and rhizome dry weight, and flowering time (weeks) and success of four calla lily cultivars irrigated with three levels of salinity applied for $63 \mathrm{~d}$ postemergence. $^{z}$

\begin{tabular}{llcr}
\hline & \multicolumn{3}{c}{ Salinity $(\mathrm{mm} \mathrm{NaCl})$} \\
\cline { 2 - 4 } & 0 & \multicolumn{1}{c}{25} \\
\cline { 2 - 4 } Run & \multicolumn{3}{c}{ Total growth $(\mathrm{cm})^{\mathrm{y}}$} \\
\hline 1 & $100.11 \pm 13.46 \mathrm{a}^{*}$ & $91.67 \pm 11.42 \mathrm{a}$ & $105.02 \pm 12.99 \mathrm{a}$ \\
2 & $127.00 \pm 15.84 \mathrm{a}$ & $95.41 \pm 15.88 \mathrm{ab}$ & $73.35 \pm 11.53 \mathrm{~b}$ \\
3 & $144.06 \pm 12.46 \mathrm{a}$ & $126.19 \pm 13.51 \mathrm{a}$ & $101.12 \pm 12.83 \mathrm{a}$
\end{tabular}

$\begin{array}{ll}1 & 1.80 \pm 0.44 \mathrm{a} \\ 2 & 2.60 \pm 0.65 \mathrm{a} \\ 3 & 2.05 \pm 0.30 \mathrm{a} \\ & \\ 1 & 3.90 \pm 0.51 \mathrm{a} \\ 2 & 3.73 \pm 0.54 \mathrm{a} \\ 3 & 5.24 \pm 0.43 \mathrm{a}\end{array}$

Flower number

$2.30 \pm 0.44 \mathrm{a}$

$1.75 \pm 0.45 \mathrm{ab}$

$2.16 \pm 0.55 \mathrm{a}$

$1.05 \pm 0.33 \mathrm{a}$

$0.95 \pm 0.31 \mathrm{~b}$

$1.20 \pm 0.25 \mathrm{a}$

Shoot dry weight (g)

$3.96 \pm 0.38 \mathrm{a}$

$2.87 \pm 0.48 \mathrm{ab}$

$4.58 \pm 0.52 \mathrm{ab}$

$2.64 \pm 0.30 \mathrm{~b}$

$1.65 \pm 0.34 \mathrm{~b}$

$3.32 \pm 0.48 \mathrm{~b}$

Rhizome dry weight (g)

$7.41 \pm 0.64 \mathrm{a}$

$6.32 \pm 0.47 \mathrm{a}$

$5.85 \pm 0.44 \mathrm{a}$

$8.90 \pm 0.63 \mathrm{a}$

$7.10 \pm 0.54 \mathrm{a}$

$6.16 \pm 0.71 \mathrm{a}$

Flowering time (weeks)

$4.31 \pm 0.27 \mathrm{a}$

$6.85 \pm 0.42 \mathrm{a}$

$4.13 \pm 0.58 \mathrm{a}$

$4.40 \pm 0.38 \mathrm{a}$

$6.44 \pm 0.47 \mathrm{a}$

$4.40 \pm 0.56 \mathrm{a}$

Flowering success $(\%)^{x}$

\begin{tabular}{ll}
80 & 83 \\
65 & 47 \\
84 & 75 \\
\hline
\end{tabular}

${ }^{2}$ For each salinity, $\mathrm{n}=20$

${ }^{\mathrm{y}}$ Total growth was obtained by measuring the height of all the stems that emerged from a rhizome minus the initial height of all stems that had emerged at the time that treatments were initiated.

${ }^{x}$ Flowering success was calculated as the number of plants in each treatment that flowered out of the number of plants that emerged. Flowering success was analyzed using ordinal logistic regression and salinity had a significant effect on flowering success only in Run 2.

*Values within the same row with the same letter were not significantly different according to Tukey's honestly significant difference at $P \leq 0.05$. collected and EC measured to approximate the change in the salinity of the soil using an HI 98311 EC/Temperature/TDS meter (Hanna Instruments, Ann Arbor, MI).

Plant evaluation when salinity was applied post-emergence. The post-emergence treatments began when $80 \%$ of the plants had emerged, which was $\approx 21 \mathrm{~d}$ after planting. There were three runs of the post-emergence experiment, which occurred Fall 2007 (Run 1), Spring 2008 (Run 2), and Fall 2008 (Run 3 ). At the time of planting, the average rhizome weight \pm SE in Run 2 was $22.99 \pm$ $0.41 \mathrm{~g}$ and for Run 3 was $22.98 \pm 0.44 \mathrm{~g}$, but these data were not collected for Run 1. Plant height and flowering status were measured weekly for $63 \mathrm{~d}$ after initiation of treatments, whereas biomass, leaf number, flower number, chlorophyll and carotenoid concentration, relative water content (RWC), and shoot and rhizome $\mathrm{Ca}^{2+}$ and $\mathrm{Na}^{+}$content were measured at harvest. To get the most accurate picture of overall plant growth, the height (in centimeters) of every stem of the plant was measured and a total growth (total height - initial height) calculated. Fresh weight of both the shoots and rhizomes were recorded at harvest, and then the samples were dried for $48 \mathrm{~h}$ at $80^{\circ} \mathrm{C}$ before dry biomass was weighed.

At harvest, a 0.5-g leaf section was taken from the upper third of the leaf for determination of RWC. Relative water content was calculated by the formula $\frac{\text { Freshweight-Dryweight }}{\text { Turgidweight }- \text { Dryweight }}$ (Bogeat-Triboulot et al., 2007). Turgid weight was determined after the leaf was immersed in distilled water for $24 \mathrm{~h}$, and dry weight was determined after the leaf was dried for $48 \mathrm{~h}$ at $80{ }^{\circ} \mathrm{C}$ (Bogeat-Triboulot et al., 2007). For pigment determination, a $0.5-\mathrm{g}$ sample of leaf was taken at harvest. The leaf sample was homogenized in $5 \mathrm{~mL}$ of $80 \%$ acetone with an additional $20 \mathrm{~mL}$ of $80 \%$ acetone added before centrifugation for a final volume of $25 \mathrm{~mL}$. The samples were centrifuged for $10 \mathrm{~min}$ at $700 \mathrm{~g}$ at $10^{\circ} \mathrm{C}$. The samples were analyzed with a light spectrometer at wavelengths of 663,646 , and $470 \mathrm{~nm}$. Chlorophyll $a$ concentration $(\mu \mathrm{g} / \mathrm{g}$ fw) was calculated using the Eq. $12.25 \mathrm{~A}_{663}-2.79 \mathrm{~A}_{646}$, chlorophyll $b$ concentration was calculated using the Eq. $21.50 \mathrm{~A}_{646}-5.10 \mathrm{~A}_{663}$, and carotenoid concentration was calculated using the Eq. $\left(1000 \mathrm{~A}_{470}-1.82\right.$ Chlor a -85.02 Chlor b)/198 (Pinhiero et al., 2008).

Shoot and rhizome $\mathrm{Ca}^{2+}$ and $\mathrm{Na}^{+}$content were analyzed using atomic absorption spectrometry (AAS) (Olsen and Ulicny, 2001). Although both $\mathrm{Na}^{+}$and $\mathrm{Cl}^{-}$are toxic ions, because in most plants $\mathrm{Na}^{+}$reaches toxic levels before $\mathrm{Cl}^{-}$does (Kingsbury and Epstein, 1986; Munns and Tester, 2008), we decided to focus our analysis on $\mathrm{Na}^{+}$. The dried shoot of each plant was crushed and the shoot sample was taken from this mix of shoot material. The dried rhizomes were broken open and the rhizome sample taken from the interior of the rhizome to avoid any contamination from salts that may have accumulated on the outside of the rhizome. Shoot and rhizome samples were wet-digested in $\mathrm{HNO}_{3}$ and $\mathrm{HClO}_{4}$ at $200{ }^{\circ} \mathrm{C}$ 
until near dryness and then removed and treated with $\mathrm{HCl}$ for $1 \mathrm{~h}$ before being diluted with double distilled water as described in Grusak (1994) and Pomper and Grusak (2004). Three blocks were used for AAS. The ratio of $\mathrm{Ca}^{2+}$ and $\mathrm{Na}^{+}$of the 25- and 50-mM NaCl treatments compared with the control was calculated by dividing the $\mathrm{Ca}^{2+}$ and $\mathrm{Na}^{+}$content $\left(\mathrm{mg} \cdot \mathrm{kg}^{-1}\right)$ of each cultivar in each treatment within a block by the corresponding cultivar being treated with the $0-\mathrm{mm} \mathrm{NaCl}$ treatment within that same block.

Plant evaluation when salinity was applied pre-emergence. The effect of saline irrigation applied pre-emergence (at the time of planting) was assessed for $105 \mathrm{~d}$ after planting, which is $\approx 1$ week before natural senescence begins (Clark and Boldingh, 1991). The average rhizome weight \pm SE at planting in Spring 2008 was $23.78 \pm 0.48 \mathrm{~g}$ and in Fall 2008 was $24.56 \pm 0.51 \mathrm{~g}$. Emergence and time to flowering were assessed daily, whereas final height, biomass of the shoot and rhizome, leaf number, flower number, and shoot and rhizome $\mathrm{Ca}^{2+}$ and $\mathrm{Na}^{+}$content were measured at harvest. The methods for biomass determination and $\mathrm{Ca}^{2+}$ and $\mathrm{Na}^{+}$content were the same as those described for the post-emergence experiment.

Statistical analyses. Growth, biomass, pigment, RWC, and plant nutrient content were analyzed with the general linear model using the fit model platform of JMP 8 (SAS Institute Inc., 1989-2008). Initial rhizome weight was used as a covariate for Runs 2 and 3 with initial height as a covariate for Run 1. Other factors included in the model were block, cultivar, salinity, and salinity $\times$ cultivar. The following transformations were done on the data to meet the assumption of normality for data analysis. Rhizome dry weight was natural log transformed in Run 1. Relative water content was sine transformed in Run 3. Shoot and rhizome $\mathrm{Ca}^{2+}$ and $\mathrm{Na}^{+}$content were natural log transformed for all analyses. Untransformed means were reported for all data. Multiple comparisons were done using Tukey's honestly significant difference. A $P$ value of $\leq 0.05$ was considered significant throughout. For all plants that emerged and flowered, the time to emergence and flowering, which excluded plants that did not emerge or flower, were analyzed using the general linear model using the fit model platform of JMP 8 (SAS Institute Inc., 19892009). The proportion of plants that emerged and flowered when the salinity treatments were applied pre-emergence was analyzed using ordinal logistic regression in the fit model platform of JMP 8 (SAS Institute Inc., 1989-2009).

\section{Results}

Soil effluent electrical conductivity. The changes in soil effluent EC over the course of the experiment are shown in Table 1. For the post-emergence experiments, the soil effluent water EC almost doubled in both the 25- and 50 -mm NaCl treatments over the 63-d treatment period. When saline irrigation was applied preemergence, the soil water EC in the 25- and 50$\mathrm{mm} \mathrm{NaCl}$ treatments doubled in the fall and tripled in the spring.
Post-emergence growth and nutrient composition. There were no significant salinity $\times$ cultivar interactions for any of the collected data, so data from all cultivars within the same salinity treatment were averaged together for the tables. Total plant growth was not significantly affected by saline irrigation in Runs 1 and 3 but was significantly reduced in the highest salinity treatment in Run 2 (Table 2). Although overall growth did not consistently vary among the three treatments, shoot biomass production was significantly reduced in all runs in the $50-\mathrm{mm} \mathrm{NaCl}$ treatment (Table 2 ). Rhizome dry weight was not significantly affected by any of the treatments (Table 2). Cultivar significantly affected flower number with 'Flame' typically producing the lowest number of flowers per plant $(0.7 \pm 0.18)$ and 'Pink Rehmanii' the most flowers per plant $(3.5 \pm 0.44)$. Flower number was not significantly affected by saline irrigation in Runs 1 and 3 but was significantly reduced in the 50$\mathrm{mm}$ treatment compared with the control in
Run 2 (Table 2). Salinity also did not have a significant effect on flowering time or on the proportion of plants that flowered (flowering success) in Runs 1 and 3; however, flowering time in Run 2 (Spring 2008) was almost 2 weeks later than flowering time in Runs 1 and 3 with lower overall flowering success in the 50mu treatment compared with the control (Table 2 ). Pigment concentration was not adversely affected by exposure to saline irrigation in all three runs. Under all three salinities, the mean pigment concentrations were consistently from highest to lowest as follows: chlorophyll $a$ $(19.65 \pm 0.35 \mu \mathrm{g} / \mathrm{g} \mathrm{fw})$, chlorophyll $b(7.53 \pm$ $0.29 \mu \mathrm{g} / \mathrm{g} \mathrm{fw})$, and carotenoids $(4.80 \pm 0.08$ $\mu \mathrm{g} / \mathrm{g} \mathrm{fw})$. The RWC of the plants was also not significantly affected by saline irrigation with an average RWC of $0.79 \pm 0.01$.

The concentration of $\mathrm{Ca}^{2+}$ in the shoots was significantly higher in the $50-\mathrm{mm}$ treatment compared with the $0 \mathrm{~mm}$ control in Runs 1 and 2 (Table 3 ). In Run 3 , the shoot $\mathrm{Ca}^{2+}$ concentration was not elevated in the $50-\mathrm{mm} \mathrm{NaCl}$

Table 3. Mean \pm SE shoot and rhizome $\mathrm{Ca}^{2+}$ and $\mathrm{Na}^{+}$concentrations of the plants exposed to 25 and $50 \mathrm{~mm}$ $\mathrm{NaCl}$ compared with the $0 \mathrm{~mm} \mathrm{NaCl}$ control and the shoot to rhizome $\mathrm{Ca}^{2+}$ and $\mathrm{Na}^{+}$ratios of four calla lily cultivars irrigated with three levels of salinity applied for $63 \mathrm{~d}$ post-emergence. ${ }^{z}$

\begin{tabular}{lccc}
\hline & \multicolumn{3}{c}{ Salinity $(\mathrm{mm} \mathrm{NaCl})$} \\
\cline { 2 - 4 } Run & 0 & 25 & 50 \\
\hline 1 & $1 \mathrm{~b}^{*}$ & ${\text { Shoot } \mathrm{Ca}^{2+}(\text { relative to control })^{\mathrm{y}}}$ \\
2 & $1 \mathrm{~b}$ & $3.00 \pm 0.67 \mathrm{a}$ & $3.37 \pm 1.14 \mathrm{a}$ \\
3 & $1 \mathrm{a}$ & $2.85 \pm 1.35 \mathrm{ab}$ & $3.96 \pm 1.43 \mathrm{a}$ \\
& & $1.26 \pm 0.33 \mathrm{a}$ & $1.36 \pm 0.32 \mathrm{a}$ \\
& $1 \mathrm{a}$ & Rhizome Ca & \\
1 & $1 \mathrm{a}$ & $1.69 \pm 0.43 \mathrm{a}$ & \\
2 & $1 \mathrm{a}$ & $1.08 \pm 0.28 \mathrm{a}$ & $1.13 \pm 0.27 \mathrm{a}$ \\
3 & & $0.91 \pm 0.24 \mathrm{ab}$ & $0.40 \pm 0.45 \mathrm{a}$ \\
& & & \\
1 & $1.06 \pm 0.39 \mathrm{~b}$ & Shoot:rhizome Ca & \\
2 & $0.25 \pm 0.07 \mathrm{a}$ & $0.80 \pm 0.22 \mathrm{ab}$ & $2.38 \pm 0.77 \mathrm{a}$ \\
3 & $0.37 \pm 0.10 \mathrm{~b}$ & $0.66 \pm 0.37 \mathrm{a}$ & $0.98 \pm 0.58 \mathrm{a}$ \\
& & $0.71 \pm 0.27 \mathrm{ab}$ & $1.44 \pm 0.55 \mathrm{a}$
\end{tabular}

$\begin{array}{ll}1 & 1 \mathrm{a} \\ 2 & 1 \mathrm{a} \\ 3 & 1 \mathrm{a} \\ & \\ 1 & 1 \mathrm{~b} \\ 2 & 1 \mathrm{~b} \\ 3 & 1 \mathrm{~b} \\ & \\ 1 & 1 \mathrm{a} \\ 2 & 1 \mathrm{~b} \\ 3 & 1 \mathrm{a}\end{array}$

Total $\mathrm{Ca}^{2+}$ (relative to control)

$1.94 \pm 0.47 \mathrm{a}$

$1.12 \pm 0.25 \mathrm{a}$

$1.51 \pm 0.47 \mathrm{a}$

$1 \mathrm{a}$

$0.95 \pm 0.26 \mathrm{a}$

$1.59 \pm 0.45$ a

Shoot $\mathrm{Na}^{+}$(relative to control)

$1.30 \pm 0.12 \mathrm{ab}$

$3.59 \pm 0.98 \mathrm{a}$

$2.70 \pm 1.32 \mathrm{ab}$

$1.43 \pm 0.17 \mathrm{a}$

$1 \mathrm{~b}$

$\mathrm{Na}^{+}$(relative to control)

$0.87 \pm 0.12 \mathrm{a}$

$2.37 \pm 0.63 \mathrm{a}$

$1.73 \pm 0.48 \mathrm{a}$

$1.22 \pm 0.18$

$1 \mathrm{~b}$

$\begin{array}{ll}1 & 2.39 \pm 0.16 \mathrm{a} \\ 2 & 1.05 \pm 0.29 \mathrm{a}\end{array}$

$3 \quad 0.77 \pm 0.14 \mathrm{~b}$

Shoot:rhizome $\mathrm{Na}^{+}$

$4.40 \pm 1.03 \mathrm{a}$

$1.95 \pm 0.65 \mathrm{a}$

$1.99 \pm 1.09 \mathrm{ab}$

$2.18 \pm 0.34$

$1.56 \pm 0.31$

\begin{tabular}{llcl} 
& & Total Na & \\
1 & $1 \mathrm{~b}$ & $1.17 \pm 0.09 \mathrm{ab}$ & $1.37 \pm 0.11 \mathrm{a}$ \\
2 & $1 \mathrm{~b}$ & $2.53 \pm 0.58 \mathrm{a}$ & $3.58 \pm 1.05 \mathrm{a}$ \\
3 & $1 \mathrm{~b}$ & $1.99 \pm 0.50 \mathrm{ab}$ & $3.97 \pm 1.93 \mathrm{a}$ \\
\hline
\end{tabular}

${ }^{\mathrm{z}}$ For each salinity, $\mathrm{n}=12$.

${ }^{y}$ The ratio of $\mathrm{Ca}^{2+}$ and $\mathrm{Na}^{+}$of the 25- and 50-mm $\mathrm{NaCl}$ treatments compared with the control were calculated by dividing the $\mathrm{Ca}^{2+}$ and $\mathrm{Na}^{+}$content $\left(\mathrm{mg} \cdot \mathrm{kg}^{-1}\right)$ of each cultivar in each treatment within a block by the corresponding cultivar being treated with the $0-\mathrm{mm} \mathrm{NaCl}$ treatment within that same block.

*Values within the same row with the same letter were not significantly different according to Tukey's honestly significant difference at $P \leq 0.05$. 
treatment compared with the control, but the rhizome $\mathrm{Ca}^{2+}$ concentration was significantly reduced compared with the control (Table 3 ). Although the total $\mathrm{Ca}^{2+}$ concentration per plant did not vary among treatments, typically the 50-mm NaCl treatment had the highest shoot: rhizome $\mathrm{Ca}^{2+}$ concentration (Table 3 ). Sodium content was significantly affected by saline irrigation with the most notable increase in $\mathrm{Na}^{+}$ content in the $50-\mathrm{mm} \mathrm{NaCl}$ treatment (Table 3). Sodium accumulated at a higher concentration in the shoots than in the rhizomes in both the $25-$ and $50-\mathrm{mm} \mathrm{NaCl}$ treatments with two to three times as much $\mathrm{Na}^{+}$in the shoots compared with the rhizomes (Table 3 ).

Pre-emergence growth, development, and nutrient composition. Season had a significant effect on almost all growth and development measurements. Total growth, shoot dry weight, and flower number were significantly reduced by the $50-\mathrm{mm} \mathrm{NaCl}$ treatment compared with the control with a greater difference observed in the spring compared with the fall (Table 4). Emergence took on average between 14 and 18 $\mathrm{d}$ both seasons with the exception of the $25-\mathrm{mm}$ $\mathrm{NaCl}$ treatment in the spring, when it took almost $26 \mathrm{~d}$ (Table 4). However, the proportion of plants that emerged (emergence success) was not significantly affected by season or salinity (Table 4). Of the plants that both emerged and flowered, the flowering time did not differ significantly among the salinities but did vary by season. The plants grown in the spring flowered almost $25 \mathrm{~d}$ later than plants grown in the fall. Flowering success was unaffected by salinity in the fall but was significantly reduced in the spring. This was particularly evident in the 50-mm NaCl treatment, which had less than $50 \%$ of the emerged plants flower (Table 4 ).

Calcium concentration and distribution when the saline irrigation was started preemergence did not show the same trend seen in the post-emergence experiments. Shoot $\mathrm{Ca}^{2+}$ was highest in the $25-\mathrm{mm} \mathrm{NaCl}$ treatment with all of the $\mathrm{Ca}^{2+}$ measurements having a large amount of variation (Table 5). Sodium concentration and distribution had a pattern similar to that observed in the post-emergence experiments. Sodium was just as high or higher in the 25- and 50-mM NaCl treatments compared with the $0 \mathrm{~mm} \mathrm{NaCl}$ control and was higher in the shoots than in the rhizomes (Table 5).

Table 4. Mean \pm SE growth, flower number, shoot and rhizome dry weight, emergence and flowering time (d), and total emergence and flowering of four calla lily cultivars irrigated with three levels of salinity for $105 \mathrm{~d}$ with treatments started preemergence. ${ }^{\mathrm{z}}$

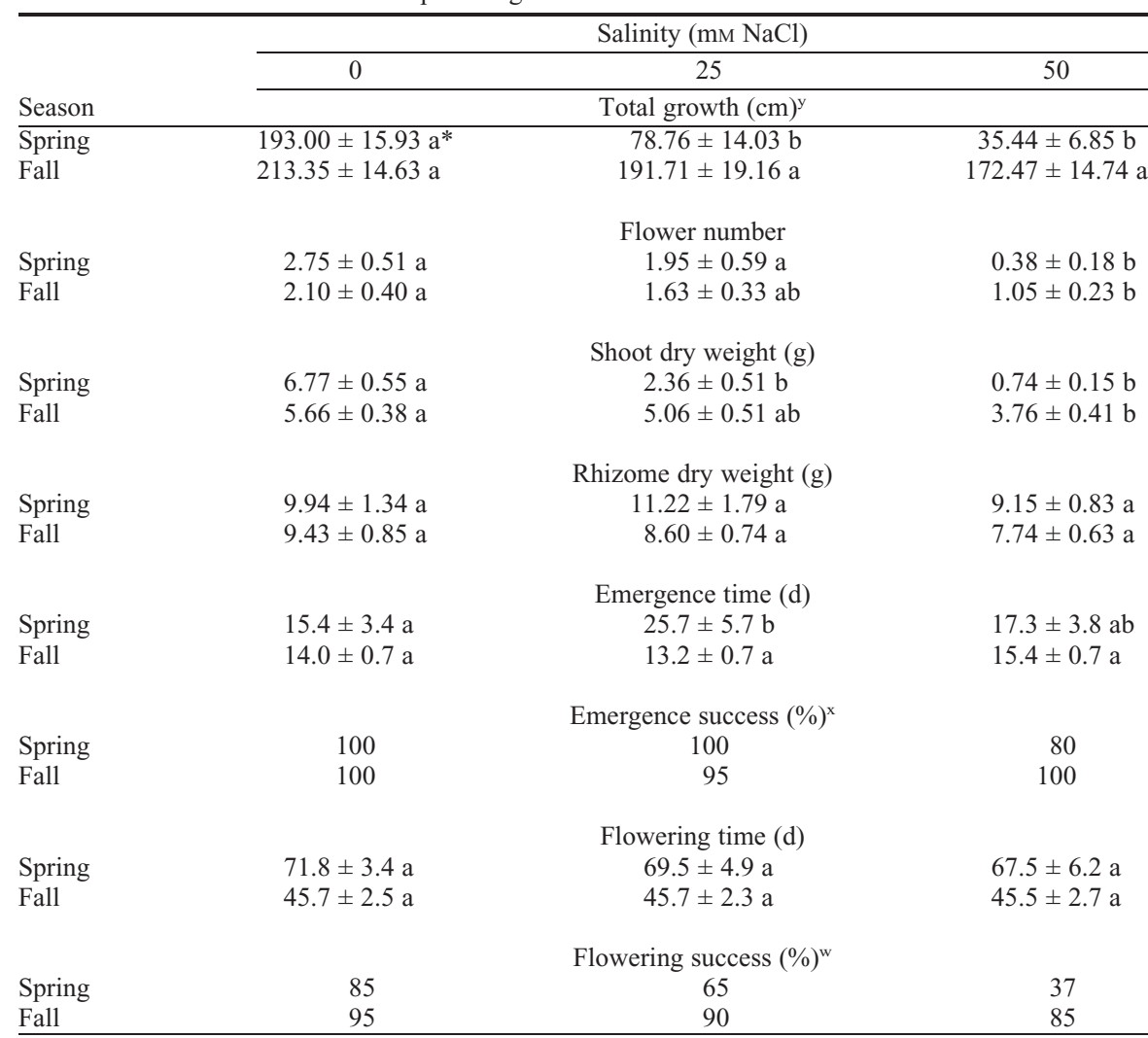

${ }^{\mathrm{z}}$ For each salinity, $\mathrm{n}=20$.

yTotal growth was calculated by measuring and adding up the height of all the stems that emerged from a rhizome.

${ }^{x}$ Emergence success was calculated as the number of plants that had stems emerge out of the total number of rhizomes planted $(\mathrm{n}=20)$ and was analyzed using ordinal logistic regression.

${ }^{\text {w}}$ Flowering success was calculated as the number of plants in each treatment that flowered out of the number of plants that emerged. Flowering success was analyzed using ordinal logistic regression and salinity had a significant effect on flowering success only in the spring.

*Values within the same row with the same letter were not significantly different according to Tukey's honestly significant difference at $P \leq 0.05$.

\section{Discussion}

Arid and semiarid areas have especially low availability of high-quality water for agricultural and horticultural purposes because more and more water is being used directly for human consumption (Carter et al., 2005; Kirzhner et al., 2008; Marcum, 2006; Shillo et al., 2002). Alternative water sources include reclaimed water and water from saline aquifers, which may have an EC that is not optimal for plant growth. For example, in the Negev Desert, there is a large saline aquifer that is being investigated for the cultivation of ornamental plants (Shillo et al., 2002), and saline ground and wastewater are being investigated for use by cut flower growers in California (Carter et al., 2005; Grieve et al., 2008). As a result of the cost of quality irrigation water and often the scarcity of high-quality water for irrigation (Arabiyat, 2005; Carter et al., 2005; Marcum, 2006; Shillo et al., 2002), a good working knowledge of how salinity affects ornamental plant quality is very important.

Calla lilies are a popular cut flower and landscape plant (Halligan et al., 2004; LealRojas et al., 2007; Martens et al., 2003; Schoellhorn, 2004). It is recommended that calla lilies be irrigated with water that has an EC $1.5 \mathrm{dS} \cdot \mathrm{m}^{-1}$ or less to avoid damage to the plants (Camberato et al., 2009; Evans, 2005; Morgan, 2006; Pacific Callas, n.d.). Our data indicate that irrigation water with a higher EC can be used without sacrificing plant quality. The plants in the $25-\mathrm{mm} \mathrm{NaCl}$ treatment with an irrigation water EC approximately twice the recommended $\mathrm{EC}$ had no significant reduction in biomass or flower number compared with the $0 \mathrm{~mm}$ control after $63 \mathrm{~d}$ of salt exposure (Table 2). Even when the exposure to $25 \mathrm{~mm}$ salinity began pre-emergence and lasted for an additional $42 \mathrm{~d}$, there was still no significant effect on flower production, and biomass production only decreased significantly in the spring (Table 4). These data provide evidence that there may be some inherent salt tolerance in colored calla lily hybrids. Although Z. aethiopica is tolerant of wet conditions and is found naturally in wetlands (Belmont and Metcalfe, 2003; Schoellhorn, 2004; Zurita et al., 2008), colored callas need well-drained soil and can be damaged by excess moisture (Naor et al., 2005; Schoellhorn, 2004). Therefore, the colored calla lily cultivars used in this study may have a history of dealing with water deficit with similar mechanisms in place to deal with physiological drought imposed by saline conditions. In addition, colored calla lilies have cDNAs that have homology to salinity response genes in Arabidopsis thaliana (L.) and Solanum tuberosum (L.) (Leal-Rojas et al., 2007), which may increase their tolerance to $\mathrm{NaCl}$. However, a decline in plant quality was observed when the irrigation water EC of greater than $6 \mathrm{dS} \cdot \mathrm{m}^{-1}$ under the $50-\mathrm{mm} \mathrm{NaCl}$ treatment. The plants in this treatment had reductions in both biomass and flower production regardless of when exposure began (Tables 2 and 4), although visually the plants appeared to be unstressed with no loss of plant pigments observed in the post-emergence study. 
Table 5. Mean \pm sE shoot and rhizome $\mathrm{Ca}^{2+}$ and $\mathrm{Na}^{+}$concentrations of the plants exposed 25 and $50 \mathrm{~mm} \mathrm{NaCl}$ compared with the $0 \mathrm{~mm} \mathrm{NaCl}$ control and the shoot to rhizome $\mathrm{Ca}^{2+}$ and $\mathrm{Na}^{+}$ratios of four calla lily cultivars irrigated with three levels of salinity applied for $105 \mathrm{~d}$ with treatment started pre-emergence. ${ }^{\mathrm{z}}$

\begin{tabular}{|c|c|c|c|}
\hline \multirow[b]{3}{*}{ Season } & \multicolumn{3}{|c|}{ Salinity (mm NaCl) } \\
\hline & 0 & 25 & 50 \\
\hline & \multicolumn{3}{|c|}{ Shoot $\mathrm{Ca}^{2+}(\text { relative to control) })^{\mathrm{y}}$} \\
\hline Spring & $1 \mathrm{a}^{*}$ & $3.90 \pm 1.60 \mathrm{a}$ & $2.24 \pm 0.65 \mathrm{a}$ \\
\hline \multirow[t]{2}{*}{ Fall } & $1 \mathrm{~b}$ & $1.92 \pm 0.28 \mathrm{a}$ & $1.69 \pm 0.43 \mathrm{ab}$ \\
\hline & \multicolumn{3}{|c|}{ Rhizome $\mathrm{Ca}^{2+}$ (relative to control) } \\
\hline Spring & $1 \mathrm{a}$ & $1.70 \pm 0.78 \mathrm{a}$ & $1.92 \pm 1.19 \mathrm{a}$ \\
\hline Fall & $1 \mathrm{a}$ & $2.69 \pm 1.43 \mathrm{a}$ & $2.49 \pm 1.20 \mathrm{a}$ \\
\hline & \multicolumn{3}{|c|}{ Shoot:rhizome $\mathrm{Ca}^{2+}$} \\
\hline Spring & $0.46 \pm 0.20 \mathrm{a}$ & $0.74 \pm 0.22 \mathrm{a}$ & $0.70 \pm 0.16 \mathrm{a}$ \\
\hline Fall & $0.57 \pm 0.17 \mathrm{a}$ & $0.61 \pm 0.12 \mathrm{a}$ & $0.51 \pm 0.15 \mathrm{a}$ \\
\hline & \multicolumn{3}{|c|}{ Total $\mathrm{Ca}^{2+}$ (relative to control) } \\
\hline Spring & $1 \mathrm{a}$ & $1.96 \pm 0.94 \mathrm{a}$ & $1.67 \pm 1.01 \mathrm{a}$ \\
\hline \multirow[t]{2}{*}{ Fall } & $1 \mathrm{a}$ & $1.72 \pm 0.56 \mathrm{a}$ & $1.65 \pm 0.47 \mathrm{a}$ \\
\hline & \multicolumn{3}{|c|}{ Shoot $\mathrm{Na}^{+}$(relative to control) } \\
\hline Spring & $1 \mathrm{~b}$ & $1.56 \pm 0.29 \mathrm{ab}$ & $1.97 \pm 0.23 \mathrm{a}$ \\
\hline \multirow[t]{2}{*}{ Fall } & $1 \mathrm{~b}$ & $1.78 \pm 1.29 \mathrm{ab}$ & $5.02 \pm 1.73 \mathrm{a}$ \\
\hline & \multicolumn{3}{|c|}{ Rhizome $\mathrm{Na}^{+}$(relative to control) } \\
\hline Spring & $1 \mathrm{~b}$ & $2.71 \pm 0.59 \mathrm{a}$ & $2.73 \pm 0.58 \mathrm{a}$ \\
\hline \multirow[t]{2}{*}{ Fall } & $1 \mathrm{a}$ & $1.25 \pm 0.12 \mathrm{a}$ & $1.47 \pm 0.25 \mathrm{a}$ \\
\hline & \multicolumn{3}{|c|}{ Shoot:rhizome $\mathrm{Na}^{+}$} \\
\hline Spring & $2.88 \pm 0.41 \mathrm{a}$ & $1.81 \pm 0.47 \mathrm{a}$ & $2.77 \pm 0.62 \mathrm{a}$ \\
\hline \multirow[t]{2}{*}{ Fall } & $1.40 \pm 0.17 \mathrm{~b}$ & $1.94 \pm 0.32 \mathrm{ab}$ & $6.07 \pm 2.28 \mathrm{a}$ \\
\hline & \multicolumn{3}{|c|}{ Total $\mathrm{Na}^{+}$(relative to control) } \\
\hline Spring & $1 \mathrm{~b}$ & $1.80 \pm 0.31 \mathrm{a}$ & $2.06 \pm 0.27 \mathrm{a}$ \\
\hline Fall & $1 \mathrm{~b}$ & $1.45 \pm 0.14 \mathrm{~b}$ & $3.32 \pm 0.89 \mathrm{a}$ \\
\hline
\end{tabular}

${ }^{\mathrm{z}}$ For each salinity, $\mathrm{n}=12$.

y The ratio of $\mathrm{Ca}^{2+}$ and $\mathrm{Na}^{+}$of the $25-$ and $50-\mathrm{mm} \mathrm{NaCl}$ treatments compared with the control were calculated by dividing the $\mathrm{Ca}^{2+}$ and $\mathrm{Na}^{+}$content $\left(\mathrm{mg} \cdot \mathrm{kg}^{-1}\right)$ of each cultivar in each treatment within a block by the corresponding cultivar being treated with the $0-\mathrm{mm} \mathrm{NaCl}$ treatment within that same block.

*Values within the same row with the same letter were not significantly different according to Tukey's honestly significant difference at $P \leq 0.05$.

Initially we speculated that the relatively good shoot visual quality of the plants exposed to the 25- and 50-mm NaCl treatments could be the result of exclusion of $\mathrm{Na}^{+}$uptake by the plant or sequestration of $\mathrm{Na}^{+}$in the rhizome. However, we observed $\mathrm{Na}^{+}$accumulation in the shoots that was significantly greater than in the control plants irrigated with the $0-\mathrm{mm}$ $\mathrm{NaCl}$ solution and was higher in the shoots than in the rhizome (Tables 3 and 5). We now hypothesize that plant visual quality may be related to the high $\mathrm{Ca}^{2+}$ concentration maintained in the shoot, which was as high or higher in the 25- and 50-mm treatments compared with the $0 \mathrm{~mm}$ control, particularly when salinity was applied post-emergence (Table 3). Under saline conditions, $\mathrm{Ca}^{2+}$ helps maintain turgor by reducing $\mathrm{K}^{+}$loss and stimulating abscisic acid production, which are critical for stomatal regulation (Bernstein, 1975; Halperin et al., 1997; Hawkins and Lewis, 1993), thereby maintaining the high RWC observed across treatments. Calcium also helps maintain cell membrane integrity and $\mathrm{N}$ uptake under saline conditions (Bernstein, 1975; Halperin et al., 1997; Hawkins and Lewis, 1993; Kinraide, 1999). However, prolonged exposure to salinity may eventually have a negative effect on $\mathrm{Ca}^{2+}$ uptake, thereby reducing its protective effects long term, daylength encountered at the onset of Run 2 and the spring pre-emergence test (Tables 2 and 4). When the experiments were performed in the fall, the plants flowered 2 to 3 weeks sooner than plants in the same experiments performed in the spring, resulting in reduced exposure time to salt stress before flowering, which may account for significantly more successful flower production at the $50 \mathrm{~mm}$ salinity in the fall compared with the spring.

Our results indicate that irrigation water that is salinized with $\mathrm{NaCl}$, with an $\mathrm{EC}$ more than twice as high as that recommended for optimal calla growth, can be used without a loss in plant quality even when it is applied before plant emergence. Without being tied to a single water source, irrigation options for calla lilies are increased, particularly in areas where high-quality water is scarce. This could result in a decrease in production costs because lower quality water is typically cheaper and more readily accessible than high-quality water that is meant for human consumption (Arabiyat, 2005; Grattan, 2002; Marcum, 2006; Shillo et al., 2002).

\section{Literature Cited}

Aitken, A.G., J.P. Kerr, E.W. Hewett, C.N. Hale, and C. Nixon. 2005. Calla lilies (Zantedeschia)-A novel export crop with a global impact. Growing Futures Case Study Series 14:1-6.

Aldesuquy, H.S. 1992. Growth and pigment content of wheat as influenced by the combined effects of salinity and growth regulators. Biol. Plant. 34:275-283.

Arabiyat, S. 2005. Water price policies and incentives to reduce irrigation water demand: Jordan case study. Options méditerranéennes, Series B, no. 52:137-151.

Auge, R.M., A.J.W. Stodola, J.L. Moore, W.E. Klingeman, and X. Duan. 2003. Comparative dehydration tolerance of foliage of several ornamental crops. Sci. Hort. 98:511-516.

because large amounts of $\mathrm{Na}^{+}$can displace $\mathrm{Ca}^{2+}$ from the soil (Fenn and Feagly, 1999; Marcum, 2006). Unfortunately, nutrient analysis of the soil effluent was not conducted so a loss of available $\mathrm{Ca}^{2+}$ was not confirmed for calla lilies.

Despite the good overall visual quality of the calla lily foliage growing under saline irrigation, there were negative effects on flower production in the 50-mm treatment (Tables 2 and 4). When salinity was applied both preand post-emergence, the reduction in flower number was significantly more severe when the plants were grown in the spring than in the fall (Tables 2 and 4). This may be related to the slightly higher temperatures experienced in the greenhouse during the spring, which could lead to increased transpirational demand with a subsequent increase in the negative effects of salt exposure. Although calla lilies are reported to be a day-neutral plant (Naor et al., 2005), in both the spring and the fall, most of the plants flowered when the daylength was 11 to $12 \mathrm{~h}$. These daylength conditions were encountered nearer the beginning of the experiment in the fall and later in the spring experiments. The longer days that were experienced at the onset of the experiment may have led to the reduced flowering time seen in Runs 1 and 3 and the fall pre-emergence test compared with the shorter

Belmont, M.A. and C.D. Metcalfe. 2003. Feasibility of using ornamental plants (Zantedeschia aethiopica) in subsurface flow treatment wetlands to remove nitrogen, chemical oxygen demand and nonylphenol ethoxylate surfactants-A laboratory-scale study. Ecol. Eng. 21: 233-247.

Bernstein, L. 1975. Effects of salinity and sodicity on plant growth. Annu. Rev. Phytopathol. 13: 295-312.

Bogeat-Triboulot, M.B., M. Brosche, J. Renaut, L. Jouve, D. Le Thiec, P. Fayyaz, B. Vinocur, E. Witters, K. Laukens, T. Teichmann, A. Altman, J.F. Hausman, A. Polle, J. Kangasjarvi, and E. Dreyer. 2007. Gradual soil water depletion results in reversible changes of gene expression, protein profiles, ecophysiology, and growth performance in Populus euphratica, a poplar growing in arid regions. Plant Physiol. 143:876-892.

Camberato, D.M., R.G. Lopez, and M.V. Mickelbart. 2009. $\mathrm{pH}$ and electrical conductivity measurements in soilless substrates. Purdue Univ. Ext. HO-237-W.

Carter, C.T., C.M. Grieve, J.A. Poss, and D.L. Suarez. 2005. Production and ion uptake of Celosia argentea irrigated with saline wastewaters. Sci. Hort. 106:381-394.

Cassaniti, C., C. Leonardi, and T.J. Flowers. 2009. The effects of sodium chloride on ornamental shrubs. Sci. Hort. 122:586-593.

HortScience Vol. 46(2) February 2011 
Charbaji, T. and Z. Ayyoubi. 2004. Differential growth of some grapevine varieties in Syria in response to salt in vitro. In Vitro Cell. Dev. Biol. 40:221-224.

Clark, C.J. and H.L. Boldingh. 1991. Biomass and mineral nutrient partitioning in relation to seasonal growth of Zantedeschia. Sci. Hort. 47: $125-135$.

Dorion, N., N. Wies, A. Burteaux, and C. Bigot. 1999. Protoplast and leaf explants culture of Lycopersicon cheesmanii and salt tolerance of protoplast-derived calli. Plant Cell 56:9-16.

Evans, C. 2005. Callafornia calla lilies. Greenhouse Prod. News 15(1).

Fenn, L.B. and S. Feagly. 1999. Review of beneficial uses of calcium and ammonium salts for stimulating plant growth and metabolite translocation. Commun. Soil Sci. Plant Anal. 30:2627-2641.

Flowers and Freshness. 2003. 10 Oct. 2009. <http:// flowersandfreshness.com $>$.

Food and Fertilizer Technology Center. 2002. Producing disease free tubers of calla lily. 1 Aug. 2007. <http://www.agnet.org/library/rh/ $2002006 \mathrm{c} />$.

Francois, L.E. and R.A. Clark. 1978. Salt tolerance of ornamental shrubs, trees and iceplant. J. Amer. Hort. Soc. 107:66-68.

Grattan, S.R. 2002. Irrigation water salinity and crop production. University of California Division of Agriculture and Natural Resources, Davis, CA. Publication 8066.

Grieve, C.M., J.A. Poss, P.J. Shouse, and C.T. Carter. 2008. Modeling growth of Matthiola incana in response to saline wastewaters differing in nitrogen level. HortScience 43:1787-1793.

Grusak, M.A. 1994. Iron transport to developing ovules of Pisum sativum. 1. Seed import characteristics and phloem iron-loading capacity of source regions. Plant Physiol. 104:649-655.

Gupta, S.D., R.M. Auge, P.D. Denchev, and B.V. Conger. 1995. Growth, proline accumulation and water relations of $\mathrm{NaCl}$-selected callus lines of Dactylis glomeratua L. Environ. Exp. Bot. 35:83-92.

Halligan, E.A., I.R. Brooking, K.A. Funnell, and J.L. Catley. 2004. Vegetative and floral shoot development of Zantedeschia 'Black Magic'. Sci. Hort. 99:55-65.

Halperin, S.J., L.V. Kochian, and J.P. Lynch. 1997. Salinity stress inhibits calcium loading into the xylem of excised barley (Hordeum vulgare) roots. New Phytol. 135:419-427.

Hasegawa, P.M., R.A. Bressan, J.K. Zhu, and H.J. Bohnert. 2000. Plant cellular and molecular responses to high salinity. Annu. Rev. Plant. Physiol. Mol. Biol. 51:463-499.

Hawkins, H.J. and O.A.M. Lewis. 1993. Effect of $\mathrm{NaCl}$ salinity, nitrogen form and calcium concentration on the growth, ionic content and gaseous exchange properties of Triticum aestivum L. cv. Gamtoo. New Phytol. 124:161-170.

Kaushal, S.S., P.M. Groffman, G.E. Likens, K.T. Belt, W.P. Stack, V.R. Kelly, L.E. Band, and G.T. Fisher. 2005. Increased salinization of freshwater in the northeastern United States. Proc. Natl. Acad. Sci. USA 102:13517-13520.

Kingsbury, R.W. and E. Epstein. 1986. Salt sensitivity in wheat. A case for specific ion toxicity. Plant Physiol. 80:651-654.

Kinraide, T.B. 1999. Interactions among $\mathrm{Ca}^{2+}, \mathrm{Na}^{+}$, and $\mathrm{K}^{+}$in salinity toxicity: Quantitative resolution of multiple toxic and ameliorative effects. J. Expt. Bot. 50:1495-1505.

Kirzhner, F., Y. Zimmels, and A. Gafhi. 2008. Effect of evapotranspiration on the salinity of wastewater treated by aquatic plants. Rev. Environ. Health 23:149-166.

Kozai, T., W. Xiao, Q.T. Nguyen, F. Afreen, and S.M.A. Zobayed. 2005. Photoautotrophic (sugar-free medium) micropropagation systems for large scale commercialization. Prop. Ornam. Plants 5:23-34.

Leal-Rojas, P.A., A. Gutierrez-Moraga, L. DestefanoBeltran, A.A. Salvo-Garrido, and M. Gidekel. 2007. Differential gene expression in calla lily plants (Zantedeschia spp.). Agrociencia 41:141152.

Marcum, K.B. 2006. Use of saline and non-potable water in the turfgrass industry: Constraints and developments. Agr. Water Mgt. 80:132-146.

Martens, S., J. Knott, C.A. Seitz, L. Janvari, S.N. $\mathrm{Yu}$, and G. Forkmann. 2003. Impact of biochemical pre-studies on specific metabolic engineering strategies of flavonoid biosynthesis in plant tissues. Biochem. Eng. J. 14:227-235.

Morgan, L. 2006. Grow gorgeous lilies hydroponically. Growing Edge 17:36.

Munns, R. and M. Tester. 2008. Mechanisms of salinity tolerance. Annu. Rev. Plant Physiol. 59: 651-681.

Naor, V., J. Kigel, M. Ziv, and M. Flaishman. 2005. A developmental pattern of flowering in colored Zantedeschia spp.: Effects of bud position and gibberellin. J. Plant Growth Regul. 23: 269-279.

Neves-Piestun, B.G. and N. Bernstein. 2001. Salinity-induced inhibition of leaf elongation in maize is not mediated by changes in cell wall acidification capacity. Plant Physiol. 125: 1419-1428

Olsen, K.G. and L.J. Ulicny. 2001. Reduction of calcium concentrations by the Brita water filtration system: A practical experiment in titrimetry and atomic absorption spectroscopy. J. Chem. Educ. 78:941.

Pacific Callas. (n.d.). Guidelines for growing in pots. 10 Oct. 2009 . < http://pacificcallas.com/ Potgrowerguidelines.htm $>$.

Pinhiero, H.A., J.V. Silva, L. Endres, V.M. Ferreira, C. de Albuquerque Camara, F.F. Cabral, J.F Oliveira, L.W. Torres de Carvalho, J.M. dos Santos, and B.G. dos Santos Filho. 2008. Leaf gas exchange, chloroplastic pigments and dry matter accumulation in castor bean (Ricinis communis, L.) seedlings subjected to salt stress conditions. Ind. Crops Prod. 27:385-392.

Pomper, K.W. and M.A. Grusak. 2004. Calcium uptake and whole-plant water use influence pod calcium concentration in snap bean plants. J. Amer. Soc. Hort. Sci. 129:890-895.

ProFlowers. 1998-2010. 10 Oct. 2009. <http://www. proflowers.com/lilies>.

Rout, G.R., A. Mohapatra, and S. Mohan Jain. 2006. Tissue culture of ornamental pot plant: A critical review on present scenario and future prospects. Biotechnol. Adv. 24:531-560.

SAS Institute Inc. 1989-2008. Jump, Version 8. SAS Institute Inc., Cary, NC.

Schoellhorn, R. 2004. Warm climate production guidelines for Zantedeschia (calla lily) hybrids. Univ. FL IFAS Commer. Floricul. Update ENHFL04-001. 1-5.

Shakirova, F.M., A.R. Sakhabutdinova, M.V. Bezrukova, R.A. Fatkhutdinova, and D.R. Fatkhutdinova. 2003. Changes in the hormonal status of wheat seedlings induced by salicylic acid and salinity. Plant Sci. 164:317322.

Shannon, M.C. and C.M. Grieve. 1999. Tolerance of vegetable crops to salinity. Sci. Hort. 78:5-38.

Shibli, R.A., M. Kushad, G.G. Yousef, and M.A. Lila. 2007. Physiological and biochemical responses of tomato microshoots to induced salinity stress with associated ethylene accumulation. Plant Growth Regulat. 51:159-169.

Shillo, R., M. Ding, D. Pasternak, and M. Zaccai. 2002. Cultivation of cut flower and bulb species with saline irrigation. Sci. Hort. 92:41-54.

Skutnik, E., A. Lukaszewska, M. Serek, and J. Rabiza. 2001. Effect of growth regulators on postharvest characteristics of Zantedeschia aethiopica. Postharvest Biol. Technol. 21: 241-246.

Sonneveld, C., R. Baas, H.H.M. Rijssen, and J. de Hoog. 1999. Salt tolerance of flower crops grown in soilless culture. J. Plant Nutr. 22: 1033-1048.

Wahome, P.K., H.H. Jesch, and I. Grittner. 2000. Effect of $\mathrm{NaCl}$ on the vegetative growth and flower quality of roses. J. Appl. Bot. 74:38-41.

Wang, Y., S. Mopper, and K.H. Hasenstein. 2001. Effects of salinity on endogenous ABA, IAA, JA, and SA in Iris hexagona. J. Chem. Ecol. 27:327-342.

Wong, M. 2005. Salinity effects in nursery and landscape plants. SCM-12 Cooperative Extension Service University of Hawai'i at Manoa.

Xiao, Y.L. and T. Kozai. 2004. Commercial application of a photoautorophic micropropagation system using large vessels with forced ventilation: Plantlet growth and production cost. HortScience 39:1387-1391.

Zollinger, N., R. Koenig, T. Cerny-Koenig, and R. Kjelgren. 2007. Relative salinity tolerance of intermountain western United States native herbaceous perennials. HortScience 42:529534.

Zurita, F., M.A. Belmont, J. De Anda, and J. Cervantes-Martinez. 2008. Stress detection by laser-induced fluorescence in Zantedeschia aethiopica planted in subsurface-flow treatment wetlands. Ecol. Eng. 33:110-118. 